International Journal of Instruction e-ISSN: 1308-1470 • www.e-iji.net

Article submission code: 20201010120105

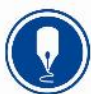

October $2021 \bullet$ Vol.14, No.4

p-ISSN: 1694-609X

pp. 135-154

Received: $10 / 10 / 2020$

Revision: 26/02/2021
Accepted: 23/03/2021

OnlineFirst: 08/07/2021

\title{
The Effectiveness of Archiving Videos and Online Learning on Student's Learning and Innovation Skills
}

\section{Cicilia Dyah Sulistyaningrum Indrawati}

Dr., Office Administration Education Study Program, Universitas Sebelas Maret, Indonesia, ciciliadyah@staff.uns.ac.id

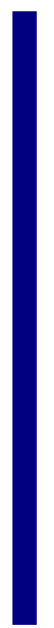

This study to analyze the level of relationship and the effect of archiving video media and online learning on students' learning and innovation skills. The research method used was a quantitative approach with a questionnaire instrument. The questionnaire was distributed to vocational students who attended the archiving subject using archiving video media that had been previously developed by the researcher. The data analysis involved prerequisite test analysis including validity and reliability tests. Furthermore, the data had to meet one of the assumption tests, which was normality. The data were analyzed using a multiple linear regression model. The results showed that (1) the use of archiving video media and online learning had a positive and significant effect on students' learning and innovation skills simultaneously, (2) the use of archiving video media had a positive and significant effect on students' learning and innovation skills, and (3) online learning had a positive and significant impact on students' learning and innovation skills. These results showed that the use of archiving video media and online learning was proven to be able to affect students' learning and innovation skills so that they can become a reference for further research.

Keywords: learning media, archiving videos, online learning, student learning and innovation skills, $21^{\text {st }}$ century skills, learning technology

\section{INTRODUCTION}

The current development continues to change. The change occurs in all aspects of life. Education is inseparable from these changes. Education must be able to carry out a structured process to create quality human resources. Technology is an important component in the development of education. The fast acceleration of technology ultimately affects the learning process in the classroom. The use of technology has begun to be carried out massively in educational research, including in the subject of entrepreneurship. The technology that is often used to improve the academic quality of entrepreneurship is digital technology. Various terms can be used to define digital technology related to the use of Information and Communication Technology (ICT). This use spreads by the terms IC, ICT, and computer literacy or digital literacy.

Citation: Indrawati, C. D. S. (2021). The Effectiveness of Archiving Videos and Online Learning on Student's Learning and Innovation Skills. International Journal of Instruction, 14(4), 135-154. https://doi.org/10.29333/iji.2021.1449a 
Technology plays an important role in defining the skills that are considered crucial. In this case, the concept can consist of main parts of it, such as computers, ICT, internet, and multimedia in combination with certain knowledge perspectives. This process completely makes use of technology. One of the media technologies that is often used for learning, particularly distance learning, is video media (Varga, 2020). This media has proven to be a medium that is broadly used in developing education (Caelles et al., 2017; Jang \& Kim, 2017; Tsai, Flagg, Nakazawa, \& Rehg, 2012; Yang, Han, Zhang, Liu, \& Zhang, 2018; D. Zhang, Han, Yang, \& Xu, n.d.). The video media is an effective medium to increase student understanding in learning (Yun, Choi, Yoo, Yun, \& Choi, 2017). The application of these media can be implemented in various methods. Media in digital form can be applied to online learning effectively (Jeffrey Alan Greene, Yu, \& Copeland, 2014; Gupta \& Dileep, 2020; Kim, Wang, \& Ketenci, 2019; Rusli, Rahman, \& Abdullah, 2020). Online learning with appropriate media content can improve the output of learning outcomes. Based on education in Indonesia, the education curriculum has been adjusted to the needs of the industrial world by integrating $21^{\text {st }}$ century skills. The $21^{\text {st }}$ century skills that are in accordance with the field of education are called learning and innovation skills or abbreviated to $4 \mathrm{C}$ skills (Mengual-Andrés, Roig-Vila, \& Mira, 2016; Schulze, Schultze, West, \& Krumm, 2017). The 4C skills are the skills of communication, critical thinking, collaboration, and creativity. The relationship between these three variables is expected to interact with each other and improve educational output in the form of learning and innovation skills. However, different opinions were expressed by Jooste et al. (2020) who stated that the success of educational programs is through material content adjusted to the world of work. This study tried to confirm whether the learning media in the form of videos that have been developed by the researcher that are integrated with online learning can improve students' learning and innovation skills. Besides, this study tried to confirm the effect of archiving video media and online learning on students' learning and innovation skills in the archiving subject. Therefore, the research problem that can be formulated are (1) do archiving video media and online learning simultaneously have a positive and significant effect on students' learning and innovation skills simultaneously? (2) Do archiving video media have a positive and significant effect on students' learning and innovation skills? (3) does online learning have a positive and significant effect on students' learning and innovation skills?

\section{Literature Review}

\section{Students' Learning and Innovation Skills}

The learning and innovation skills are one part of $21^{\text {st }}$ century skills. The $21^{\text {st }}$ century skills were first formulated completely and in line with the learning curriculum by (Voogt \& Roblin, 2012). According to Ongardwanich, Kanjanawasee, \& Tuipae, (2015), the $21^{\text {st }}$ century digital skills consist of 3 main elements. The first element is learning and innovation skills. This element consists of some components which are commonly called 4C. These components are creativity, communication, critical thinking, and collaboration. The second element is called information, media, and technology skills. These skills also have some components or indicators. The indicators 
on the elements of information, media, and technology skills are information literacy, media literacy, and information, communication, and technology literacy. The last element of the $21^{\text {st }}$ century digital skills is life and career skills. This element has 5 indicators, including flexibility and adaptability, initiative and self-direction, social and cross-cultural skills, productivity and accountability, leadership and responsibility. Based on the three elements of the $21^{\text {st }}$ century skills, the first and foremost form of learning is the learning and innovation skills. It is proven that indicators in learning and innovation skills are implemented in the current education curriculum in Indonesia. It can be concluded that the learning and innovation skills of students are one of the $21^{\text {st }}$ century skill elements that can be used for the development of the quality of human resources and have four main indicators commonly called $4 \mathrm{C}$, including skills of communication, critical thinking, collaboration, and creativity.

\section{Communication skills}

Communication skills are skills in delivering information to others and ensuring that the meaning that is expressed to others can be conveyed effectively through certain media (Benson \& Benson, 2014; Claro et al., 2012; Dass, 2014; (Laar, Deursen, Dijk, \& Haan, 2020; Mohamad, Osman, Mastura, \& Soh, 2011). The medium used refers to the individual's skills to make connections in instrumental or expressive returns (Lee \& Chen, 2017). The main component of communication skills is delivering information (Claro et al., 2012). Delivering information means using the media to effectively convey information and ideas to others (Musa, Mufti, Latiff, \& Amin, 2012; Pheeraphan, 2013; Siddiq, Scherer, \& Tondeur, 2016; Slota, Mclaughlin, Bradford, Julia, \& Vittone, 2017; van Laar, van Deursen, van Dijk, \& de Haan, 2018; Wilson, Whyte, Gangadharan, \& Kent, 2017). In a similar study, van Laar et al. (2018) stated that the study of communication is divided into 4 broad categories, including conformity, expansion, profile, and networks.

\section{Critical thinking skills}

Critical thinking is a skill in using all cognitive potential in generating new or previously unknown ideas and then treating familiar ideas in new ways and turning those ideas into a product, service, or process that is recognized as a novelty in a particular scope (de Bruin \& van Merriënboer, 2017; van Laar, van Deursen, van Dijk, \& de Haan, 2017). The main component in creativity skills is creating content or product which means using particular media to maximize cognitive potential in generating ideas or developing new ways of carrying out things (Bell \& Loon, 2015; Bucaro, 2018; Chaijaroen, Kanjug, \& Samat, 2012; Forawi, 2016; Hinrichsen \& Coombs, 2013). The main components of critical thinking skills are clarification, judgment, justification, connecting ideas, and novelty. Clarification is using the media to ask and answer questions about a problem. Assessment is assessing the suitability of a source for a given problem. Justification is submitting arguments in claims based on consistency with other claims of knowledge. Connecting ideas is to use all the potential to connect data, ideas and arguments. Novelty is to suggest new ideas in the discussion (J. A Greene, Yu, \& Copeland, 2014; Ismail, Harun, Aman, Megat, \& Salleh, 2018; Smith, 2018; Villalba \& Cedefop, 2017; Wechsler et al., 2017). 


\section{Collaboration skills}

Collaboration is a skill to develop social networks and work in teams to share information, negotiate agreements, and make decisions with mutual appreciation and respect for each other to achieve common goals (van Laar et al., 2017). The main components of collaboration skills are interactive communication and participation in discussions (Choy, Deng, Chai, Koh, \& Tsai, 2016). Interactive communication is generating meaning through the exchange of information using various media. Participation in discussions is sharing ideas. Indicators of collaboration can be in the form of responsibility, planning, interdependence, and sharing of knowledge.

\section{Creativity skills}

Creativity is the skill that generates new or previously unknown ideas and then treating familiar ideas in new ways and turning those ideas into a product, service, or process that is recognized as a novelty in a particular scope (van Laar et al., 2017). The main component of creativity skills is creating content or product which means using ICT to generate ideas or developing new ways of carrying out things (Hinrichsen \& Coombs, 2013).

\section{Archiving Video Media}

Learning media and methods that are in line with the learning material have a great effect on student learning outcomes (Clark, R, 2016; Islami \& Yondri, 2016; Meyer, Omdahl, \& G, 2010). Learning media is part of the components of teaching materials used to deliver information to students, so that learning media have to be made attractive so that students can receive it appropriately and optimally. In line with this matter, the media is a tool to provide stimulation to students so that the learning process can be carried out (Anwar, Zulkifli, Syafar, \& Jafar, 2020; Fleck, Beckman, Sterns, \& Hussey, 2014). This process is applied in the 2013 curriculum which focusses on learning by doing as an approach to developing student competencies, which is expected to improve students' problem-solving and critical thinking skills in the learning process. This competency process can be increased through a scientific approach, including observing, asking, presenting, reasoning, and trying. These competencies can be optimized by applying student-centered learning, in which students can learn independently by solving problems given to them. Archiving video media used in this study is the development from Wahyu, Wirawan, Dyah, Indrawati, \& Rahmanto (2017).

\section{Online Learning}

Online learning is the main activity in education during current world conditions. Findings from Kumari, Hemalatha, Ali, \& Naresh (2020) who conducted a survey of some stakeholder components who perceive the use of one of the online learning applications, stated that it can improve skills, especially in the mastery of technology, although on the other hand, it can reduce the level of interaction intensity. The success of components in online learning can be measured. The components can be developed based on respondents' perceptions. The study conducted by Rusli, Rahman, \& Abdullah (2020) stated that the parameters that can be measured in perceptions of online learning 
are the level of understanding of the internet, the time it takes to browse the internet in one day, opinions on online learning, the level of approval of online learning media, the level of agreement with the learning methods used, and the benefits of online learning. In establishing the $21^{\text {st }}$ century digital skills, one component is even needed, which is critical thinking (Laar et al., 2020; van Laar et al., 2017, 2018).

\section{The Effect of Archiving Video Media and Online Learning on Learning and} Innovation Skills

New technology in the education world creates opportunities for educators or teachers to take advantage of this technology to support teaching and learning processes and activities in the classroom and outside the classroom (Akyuz \& Yavuz, 2015). Besides facilitating the delivery of material from teachers to students, the use of learning media can also increase student interest and willingness in particular subjects. Media is greatly required in distance learning. One of distance learning is online learning. Online learning is the main activity in education during the current world conditions. The findings by Chen, et al. (2017) who conducted a survey to some stakeholder components who perceived the use of an online learning application, stated that it could increase skills, particularly in the mastery of technology, although it could reduce the intensity of interaction on the other hand. Online Learning has several components that its success can be measured. The components can be formed based on respondents' perceptions. Research conducted by Maryuningsih, et al. (2019) argued that the parameters that could be measured in perceptions of online learning were the level of understanding of the internet, the time required to browse the internet in one day, opinions on online learning, the level of acceptance of online learning media, the level of acceptance with the learning method used, the benefits of online learning. In the formation of $21 \mathrm{st}$ century digital skills, one component is needed, which is critical thinking (Laar, et al., 2018, 2020; van Laar et al., 2017). Students' skills, especially those related to learning and innovation skills, can be improved through media and learning. These skills include the skills of critical thinking, creativity, communication, and collaboration in accordance with the needs of the professional world of work (Laar, et al.,, 2018).

This study tried to find the effect of archiving video media and online learning variables on students' learning and innovation skills. The effect of archiving video media and online learning variables can be either simultaneously or partially to each variable. The results of this study are expected to be able to provide answers about the theoretical framework of learning and innovation skills which is affected by media and learning factors. The hypotheses that can be formulated include (1) video archiving media and online learning simultaneously have a positive and significant effect on students' learning and innovation skills simultaneously (2) archiving video media has a positive and significant effect on students' learning and innovation skills (3) online learning has a positive and significant effect on students' learning and innovation skills.

\section{METHOD}

This study was conducted at schools in Indonesia that had implemented archiving videos that the researcher had developed. There were 12 vocational schools that had received 
this video development. The study was conducted from May 2020 to August 2020. The method used in this study was quantitative research with descriptive research type. This study used a descriptive quantitative method because it tried to solve existing problems based on data so that it was in the form of numbers then analyzed and interpreted. The variables in this study consisted of archiving video media as the X1 variable (independent), online learning as the X2 variable (independent), and students' learning and innovation skills variable as the $\mathrm{Y}$ variable (dependent).

The population in this study were all 10th grade students in the Office Administration Department who had been received the archiving subject using archiving video media. The population was 1,960 with a sample of 90 students. The age range of the students who became respondents was 15 to 18 years. The sample was collected from schools that had used archiving video media and was collected using the sampling method, which was simple random sampling. This method used a lottery as used in rotating savings and was taken randomly by the researcher to meet the total number of samples planned. This sample was collected from 9 variable indicators multiplied by 10 . This is based on the opinion of Meyers et. al. (2016) which stated that in multivariate research, the sample size must be several times (5-10 times) the number of variables studied. The sampling technique used in this study was probability sampling with the type of proportional stratified random sampling. The proportional stratified random sampling technique is a side technique in which the population is grouped into particular strata then taken randomly with a balanced proportion based on the position in the population. The use of this sampling technique is based on a population that is homogeneous and has a definite number.

\section{Preliminary Observation}

This opinion is supported by preliminary observations made on 30 secondary vocational school students in Indonesia who have used archiving video media. The preliminary observation was made to students randomly by giving a questionnaire to measure learning and innovation skills consisting of communication skills, critical thinking skills, creativity skills, and collaboration skills. The questionnaire consisted of several statements describing the suitability of the respondent or commonly called an attitude statement. The questionnaire filled out by the respondents consisted of 4 main materials which were components of learning and innovation skills. The communication skills consisted of several statements, such as sharing ideas, listening to ideas, ability to convey, and being active in groups. The creativity skills consisted of generating new ideas, the use of different learning strategies, a passion for creative products, the ability to lead groups in expressing new ideas. The collaboration skills consisted of the ability to complete tasks in groups, help each other, be tolerant, and be productive in groups. The critical thinking skills consisted of the ability to solve problems, find correct information, express opinions, and the ability to reason. The results of these observations are as follows: 
Table 1

The results of initial observations of students' learning and innovation skills

\begin{tabular}{llll}
\hline No & $\begin{array}{l}\text { Students' Learning and Innovation } \\
\text { Skills (4C) }\end{array}$ & Average Answers & $\begin{array}{l}\text { Frequently Appeared } \\
\text { Questions }\end{array}$ \\
\hline 1 & Communication Skills & 2.59 & 3 \\
\hline 2 & Creativity Skills & 2.6 & 2 \\
\hline 3 & Collaboration Skills & 2.64 & 3 \\
\hline 4 & Critical Thinking Skills & 2.55 & 3 \\
\hline
\end{tabular}

Source: Primary data processed, 2020

Based on table 1, the students' average answers are between the agree in point 3 and disagree answers in point 2. The average of students' answers is 2.59 in communication, 2,6 in creativity, 2,64 in collaboration, and 2,55 in critical thinking. Whereas in the frequently appeared answers, many students answered disagree to the creativity skills which shows that this skill is still low.

\section{Test Prerequisite Analysis}

Validity and Reliability Tests

The validity test used the moment product formula with the help of SPSS 23. The research criteria required $r$ count $>r$ table. The analysis of this study showed that the $r$ table was 0.36 . The results of the validity test showed that there were 26 statement items that met the criteria for $r$ count $>r$ table, while 5 statements were declared not meeting the criteria. These results can still be used to test the hypotheses because each variable indicator had a representative statement to be answered by the respondents. The reliability test results are considered to be reliable if they meet the requirements of Cronbach's alpha of $\geq 0.60$. The reliability showed that the statement items had a value of 0.812 . These results showed that the questionnaire was feasible to distribute.

In this study, the validity test used was the construction validity with the Pearson formula (product moment) from Pearson with rough numbers, which was as follows:

$$
\mathrm{r}_{\mathrm{xy}}=\frac{N \sum X Y-\left(\sum X\right)\left(\sum Y\right)}{\sqrt{\left.\left\{N \sum X^{2}-\left(\sum X^{2}\right)\right\} N \sum Y^{2}-\left(\sum Y\right)^{2}\right\}}}
$$

Notes:

rxy : Correlation coefficient

$\mathrm{n} \quad$ : Number of subjects or respondents

$\mathrm{x} \quad$ : Item score

y : Total score

The data collection technique used a closed questionnaire with a Likert scale of 1-4. The questionnaire was used to measure the level of students' learning and innovation skills. Moreover, the questionnaire was also used to measure the effectiveness of using archiving video media and students' perceptions of online learning. The validity technique used the Pearson formula (product moment) with the criteria of $r$ count $>r$ 
table, while the reliability used the Cronbach's alpha formula with the criteria of $\geq 0.60$. The assumption test used the Kolmogorov Smirnov normality test with criteria of more than 0.05 at a tolerance of $5 \%$. The hypothesis testing used multiple linear regression models with the SPSS version 23 application.

\section{FINDINGS}

This study used three main variables to analyze. These variables were archiving video media, online learning, and students' learning and innovation skills. There were two types of variables, including the dependent variable and the independent variable. The dependent variable in this study was the student's learning and innovation skills, while the independent variables were two variables, including archiving video media and online learning. All variables were measured using a closed questionnaire instrument with a 1-4 Likert scale. The analysis used was descriptive analysis with a quantitative approach and measurement with multiple linear regression methods.

\section{Hypothesis testing}

Normality test

Table 2

Normality test results

One-Sample Kolmogorov-Smirnov Test

\begin{tabular}{lll}
\hline & & Unstandardized Residual \\
\hline $\mathrm{N}$ & & 90 \\
\hline Normal Parameters & & \\
& Mean & 0.0000000 \\
\cline { 2 - 3 } & Std. Deviation & 3,40997003 \\
\hline Test Statistic & & 0.081 \\
\hline Asymp. Sig. (2-tailed) & & 0.191 \\
\hline
\end{tabular}

Source: Primary data processed, 2020

Based on table 2, the results of the normality test are at sig. $0.191>0.05$. These results show that the research data are normally distributed and can be used for hypothesis analysis.

\section{Frequency distribution}

Before conducting multiple linear regression analysis, the frequency distribution of the data needs to be made. The following is the frequency distribution table:

Table 3

Frequency distribution

\begin{tabular}{lllll}
\hline & & TotalY & TotalX1 & TotalX2 \\
\hline $\mathrm{N}$ & Valid & 90 & 90 & 90 \\
\cline { 2 - 5 } & Missing & 0 & 0 & 0 \\
\hline Mean & 2.43 & 2.28 & 2.39 \\
\hline Median & 2.00 & 2.00 & 2.00 \\
\hline Mode & 2 & 2 & 2 \\
\hline Std. Deviation & 0.498 & 0.498 & 0.490 \\
\hline
\end{tabular}

Source: Primary data processed, 2020 
Table 3 shows the frequency distribution of the data tabulations that have been made. Line $\mathrm{N}$ shows that the number of valid data is 90 data. The mean line describes the average of the answers to each variable. Median shows the middle value of the data, while the mode is frequently appeared or answered numbers or answers by the respondent. The standard deviation shows the average disperse of the data, which means the number of deviations from the average in each variable data.

\section{Hypothesis testing}

The relationship among variables can be illustrated as follows:

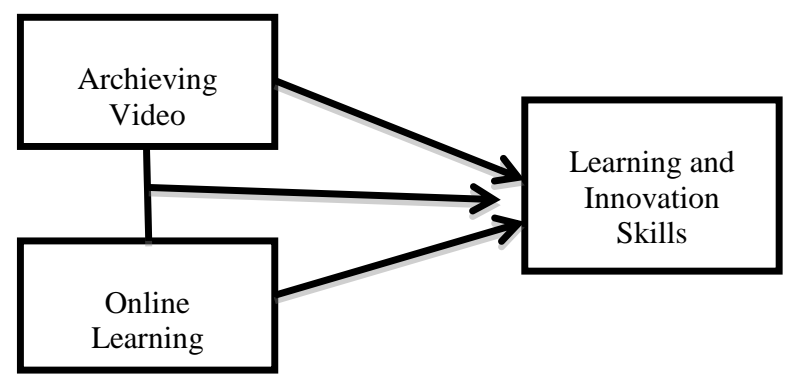

The first analysis carried out in the hypothesis test is multiple regression analysis. Following are the results of the analysis:

Table 4

Multiple regression test results

\begin{tabular}{|c|c|c|c|c|c|}
\hline \multirow[b]{2}{*}{ Model } & \multicolumn{2}{|c|}{ Unstandardized } & \multirow{2}{*}{$\begin{array}{l}\text { Standardized } \\
\text { Beta }\end{array}$} & \multirow[b]{2}{*}{$\mathrm{t}$} & \multirow[b]{2}{*}{ Sig. } \\
\hline & $\mathrm{B}$ & Std. Error & & & \\
\hline 1 (Constant) & 4.296 & 1.767 & & 2.431 & 0.017 \\
\hline TotalX1 & 0.476 & 0.112 & 0.227 & 4.231 & 0.000 \\
\hline TotalX2 & 1.075 & 0.072 & 0.800 & 14.906 & 0.000 \\
\hline
\end{tabular}

Source: Primary data processed, 2020

Based on the table above, the following equation can be formulated

$\mathrm{Y}=4.296+0.476 \mathrm{X} 1+1.075 \mathrm{X} 2$

The explanation of the table above is followed by a multiple linear regression formula that can provide an overview of the specific relationship. The explanation of the table and formula above is as follows: first, the constant was 4.296, meaning that if the archiving video media (X1) and online learning (X2) variables are constant, the student's learning and innovation skills (Y) is 4.296. The value of X1 was 0.476, meaning that if the archiving video media variable increases by 1 unit, the students' learning and innovation skills increase by 0.476 . Third, the value of $\mathrm{X} 2$ was 1.075 , meaning that if the learning variable in the network increases by 1 unit, the students' learning and innovation skills will increase by 1.075 .

The variable of student learning and innovation skills was a composite variable consisting of 4 sub-variables, including communication skills, collaboration, critical thinking skills, and creativity skills. This variable was the dependent variable measured 
using a closed statement questionnaire based on these four sub-variables. The archiving video media variable was the independent variable measured using indicators, including the operation of the media, understanding the material from the media, and the usefulness of the media. The third variable was online learning which was also measured using a questionnaire based on indicators, including the level of understanding of the internet, the time required to browse the internet in one day, opinions on online learning, the level of acceptance of online learning media, the level of acceptance with the learning method used, the benefits of online learning. Next, the correlation analysis was conducted. Following are the results of the analysis:

Table 5

Correlation analysis

\begin{tabular}{lllll}
\hline \multicolumn{2}{l}{ Model Summary } & & \\
\hline Model & R & R Square & Adjusted R Square & Std. Error of the Estimate \\
\hline 1 & 0.871 & 0.758 & 0.752 & 1.701 \\
\hline
\end{tabular}

Source: Primary data processed, 2020

Based on table 5 , it is found that the correlation $(\mathrm{R})$ of 0.871 is significant at alpha $=$ 0.05 . These results show that there is a strong and significant relationship between the variables of video archiving media and online learning with students' learning and innovation skills. The coefficient of determination $\mathrm{R}^{2}$ or in the table is called the adjusted $\mathrm{R}$ square is $0.752(75.2 \%)$. These results show that the variation of students' learning and innovation skills variable can be explained by the video archiving and online learning variables by $75.2 \%$ and the remaining $24.8 \%$ can be explained by other variables outside the variables analyzed. The next analysis is the simultaneous F test. Following are the results of the simultaneous F test:

Table 6

F test

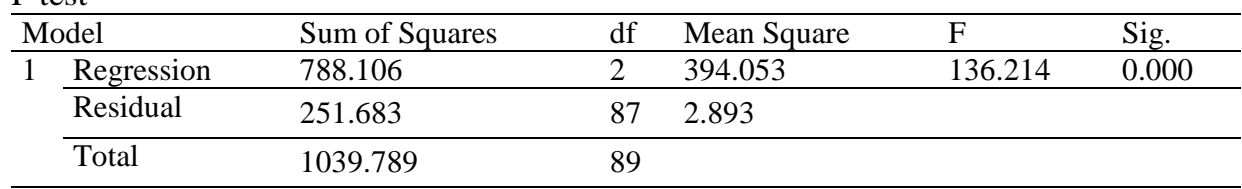

Source: Primary data processed, 2020

These results show that $\mathrm{F}$ count is higher than $\mathrm{F}$ table, which is $136.214>2.711$. It can be concluded that the archiving video media variable (X1) and the online learning variable (X2) have a positive and significant effect on students' learning and innovation skills (Y) simultaneously.

Table 7

\begin{tabular}{llll} 
T test & & & \\
\hline Model & & $\mathrm{t}$ & Sig. \\
\hline 1 & (Constant) & 2.431 & 0.017 \\
\cline { 2 - 4 } & TotalX1 & 4.231 & 0.000 \\
\cline { 2 - 4 } & TotalX2 & 14.906 & 0.000 \\
\hline
\end{tabular}

Source: Primary data processed, 2020 
Based on table 7 , the $t$ value of the archiving video media variable is $4.231>t$ table, which is 1.98 and the value of sig. is $0.000<0.05$. This means that there is a significant effect between the archiving video media variable (X1) and the learning and innovation skills variable (Y) partially. The $\mathrm{t}$ count value of online learning is $14.906>t$ table is 1.98 and the value of sig. is $0.000<0.05$. This means that there is a significant effect between the online learning variable (X2) on the students' learning and innovation skills variable (Y) partially.

\section{DISCUSSION}

The overall results of the analysis are discussed in the discussion section. The first stage was the analysis of the regression function, then the correlation and determining the determinant. Furthermore, a simultaneous test (F test) was carried out on the effect of the archiving video variable and online learning variable on students' learning and innovation skills in the archiving subject. After knowing the significance in the simultaneous test, then a partial test was carried out by considering the relationship between the three variables. There are many studies on learning and innovation skills of the 4 main components, both researched simultaneously and partially for each component. There are many ways to improve these skills, one of which is through learning media that is attractive and able to stimulate student skills (Albina \& Sumagaysay, 2020; Burbules, Fan, \& Repp, 2020; Haubold, Mathai, \& Pyenson, 2020). However, on the other hand, a different opinion was argued by Jooste et al. (2020) which stated that the success of educational programs is through material content and massive training adjusted to the world of work. Besides, the results of a study from Scott (2009) concluded that the use of IT does not seem to have a substantive effect on student performance, in this case, it means that the use of technology has not fully been able to improve the students' learning and innovation skills. This study answered the debate on the importance of learning and innovation skills among researchers. This study proved that these skills are important in preparing students to face the global challenges of the 21 st century and it is proven that, through interesting learning media, it can be one of the variables that can affect the formation and development of these skills.

\section{The Effect of Archiving Video Media and Online Learning on Students' Learning} and Innovation Skills Simultaneously

Hypothesis 1 was accepted and stated that there is a positive and significant effect of video archiving media and online learning variables on students' learning and innovation skills simultaneously. These results are consistent with the findings of some researchers. The development of video media is indeed very important in learning (Ye et al., 2020; Dongsong Zhang, Zhou, Briggs, \& Nunamaker, 2006). The learning process can be more meaningful when integrating video into online learning (Kramer, König, Strauß, \& Kaspar, 2020; Ye et al., 2020). The use of video in online learning is closely related to meeting the objective of improving student skills, especially in 21 st century skills (Bieman, Ridder, \& Gent, 2020). One of the skills that can be developed in improving the quality of human resources is the ability which consists of communication, critical thinking skills, collaboration, and creativity (Ahmed, 2020; Kim et al., 2019; Wang, Antonenko, \& Dawson, 2020). 


\section{The Effect of Archiving Video Media on Students' Learning and Innovation Skills}

Hypothesis 2 was accepted and stated that there is a positive and significant effect of the archiving video media variable on students' learning and innovation skills. Video media is designed to develop students' critical thinking skills (Selat, Lanang, Kartika, Tastra, \& Suwatra, 2014; Thomas, 2019). Besides critical thinking skills, video media in particular lessons can enhance other skills, such as communication, creativity, and collaboration with peers (Luke \& Hogarth, 2011; Mohammed, Qadha, \& Alward, 2020). Moreover, the video using simulated archiving practice content will make it easier for students to understand (Vokasi, Wibisono, Dyah, \& Indrawati, 2017; Wahyu et al., 2017).

\section{The Effect of Online Learning on Students' Learning and Innovation Skills}

Hypothesis 3 was accepted and stated that there is a positive and significant effect of the online learning variable on students' learning and innovation skills. Online learning is structured and taught to provide a new style of student learning (Series, 2019; Singh \& Thurman, 2019). The goal is not different from ordinary learning, which is to provide understanding to students (Maddison, Doi, Lucky, \& Kumaran, 2017; Nur \& Wan, 2019). In a further development, online learning can accommodate the soft skills required to enrich the quality of human resources in modern times (Chou, Wu, \& Tsai, 2018; Nortvig, Petersen, \& Balle, 2018; Sulisworo, Ummah, Nursolikh, \& Rahardjo, 2020).

\section{CONCLUSIONS}

The results show that the archiving learning video variable and the online learning variable are proven to have a positive and significant effect on students' learning and innovation skills both simultaneously and partially. This will be very useful when education is experiencing which requires distance learning from each student's home. The use of archiving video media developed by the researcher and then integrated with online learning is effective in increasing student learning and innovation skills in the archiving subject.

\section{REFERENCES}

Ahmed, W. (2020). Blending QR code with video learning in the pedagogical process for the college foundation level. Interactive Technology and Smart Education. 17(1), 67-85. https://doi.org/10.1108/ITSE-08-2019-0043

Akyüz, S., \& Yavuz, F. (2015). Digital Learning in EFL Classrooms. Procedia - Social and Behavioral Sciences, 197, 766-769. https://doi.org/10.1016/j.sbspro.2015.07.176

Albina, A. C., \& Sumagaysay, L. P. (2020). Employability tracer study of Information Technology Education graduates from a state university in the Philippines. Social Sciences \& Humanities Open, 2(1), 1-6. https://doi.org/10.1016/j.ssaho.2020.100055.

Anwar, A. I., Zulkifli, A., Syafar, M., \& Jafar, N. (2020). Effectiveness of counseling with cartoon animation audio-visual methods in increasing tooth brushing knowledge 
children ages 10-12 years. Enfermería Clínica, 30, 285-288.

Authors, F. (2015). Video Reflection in Literacy Teacher Education and Development: Lessons from Research and Practice Article information, 5, 21-40.

Bell, R., \& Loon, M. (2015). The impact of critical thinking disposition on learning using business simulations. International Journal of Management Education, 13(2), 119-127. https://doi.org/10.1016/j.ijme.2015.01.002

Benson, B. J., \& Benson, B. (2014). Domain of Competence: Interpersonal and Communication Skills. Academic Pediatrics, 14(2), S55-S65. https://doi.org/10.1016/j.acap.2013.11.016

Bieman, J. P. Den, Ridder, M. P. De, \& Gent, M. R. A. Van. (2020). Deep learning video analysis as measurement technique in physical models. Coastal Engineering, 158(December 2019). https://doi.org/10.1016/j.coastaleng.2020.103689

Bucaro, A. C. (2018). Accounting, Organizations and Society Enhancing auditors â $€^{\mathrm{TM}}$ critical thinking in audits of complex estimates *. Accounting, Organizations and Society, 73, 35-49. https://doi.org/10.1016/j.aos.2018.06.002

Burbules, N. C., Fan, G., \& Repp, P. (2020). Five trends of education and technology in a sustainable future. Geography and Sustainability, 1(2), 93-97. https://doi.org/10.1016 j.geosus.2020.05.001.

Caelles, S., Maninis, K.-K., Pont-Tuset, J., Leal-Taixé, L., Cremers, D., \& Gool, L. Van. (2017). One-shot video object segmentation. Proceedings of the IEEE Conference on Computer Vision and Pattern Recognition, 221-230.

Chaijaroen, S., Kanjug, I., \& Samat, C. (2012). The study of learners ' critical thinking potential , learning with innovation enhancing thinking potential. 46, 3415-3420. https://doi.org/10.1016/j.sbspro.2012.06.076

Chen, A. K., Dennehy, C., Fitzsimmons, A., Hyde, S., Lee, K., Rivera, J., ... Wamsley, M. (2017). Teaching interprofessional collaborative care skills using a blended learning approach. Journal of Interprofessional Education and Practice, 8, 86-90. https://doi.org/10.1016/j.xjep.2017.07.002

Chou, T., Wu, J., \& Tsai, C. (2018). Features of Critical Thinking Studies in Environments, Journal of Educational Computing Research, 57(4), 1038-1077. https://doi.org/10.1177/0735633118774350

Choy, D., Deng, F., Chai, C. S., Koh, H. L. J., \& Tsai, P. S. (2016). Singapore primary and secondary students' motivated approaches for learning: A validation study. Learning and Individual Differences, 45, 282-290. https://doi.org/http://dx.doi.org/10.1016/ j.lindif.2015.11.019

Clark, R, E. (2016). Media will never influence learning. Educational Technology Research and Development, 42, 21-29.

Claro, M., Preiss, D. D., San Martín, E., Jara, I., Hinostroza, J. E., Valenzuela, S., \& 
Al., E. (2012). Assessment of 21st century ICT skills in Chile: Test design and results from high school level students. Computers \& Education, 59(3), 1024-1053. https://doi.org/http://dx.doi.org/10.1016/j.compedu.2012.04.004.

Dass, R. (2014). Literature and the 21st century learner. Procedia - Social and Behavioral Sciences, 123, 289-298. https://doi.org/10.1016/j.sbspro.2014.01.1426

de Bruin, A. B., \& van Merriënboer, J. J. (2017). Bridging cognitive load and selfregulated learning research: A complementary approach to contemporary issues in educational research. Learning and Instruction, 51, 1-9.

Fishman, B.J. (2003). Linking on-line video and curriculum to leverage. Brophy, J. (Ed.) Using Video in Teacher Education (Advances in Research on Teaching, Vol. 10), Emerald Group Publishing Limited, Bingley, pp. 201-234 https://doi.org/10.1016/ S1479-3687(03)10008-9

Fleck, B. K. B., Beckman, L. M., Sterns, J. L., \& Hussey, H. D. (2014). YouTube in the classroom: Helpful tips and student perceptions. The Journal of Effective Teaching, 14, 21-37.

Forawi, S. A. (2016). Standard-based science education and critical thinking. Thinking Skills and Creativity, 20, 52-62. https://doi.org/10.1016/j.tsc.2016.02.005

Greene, J. A., Yu, S. B., \& Copeland, D. Z. (2014). Measuring critical components of digital literacy and their relationships with learning. Computers \& Education, 76, 5569. https://doi.org/http://dx.doi.org/10.1016/j.compedu.2014.03.008

Greene, J. A., Yu, S. B., \& Copeland, D. Z. (2014). Measuring critical components of digital literacy and their relationships with learning. Computers \& Education, 76, 55-69. https://doi.org/10.1016/j.compedu.2014.03.008

Gupta, S., \& Dileep, A. D. (2020). Neurocomputing Relevance feedback based online learning model for resource bottleneck prediction in cloud servers. Neurocomputing, 402, 307-322. https://doi.org/10.1016/j.neucom.2020.04.080

Haubold, H. J., Mathai, A. M., \& Pyenson, L. (2020). Space Science and Technology Education, Teaching, Research. Space Policy, 53, 1-3. https://doi.org/10.1016/ j.spacepol.2020.101384.

Hinrichsen, J., \& Coombs, A. (2013). The five resources of critical digital literacy: A framework for curriculum integration. Research in Learning Technology, 21, 1-16. https://doi.org/http://dx.doi.org/10.3402/rlt.v21.21334

Islami, S., \& Yondri, S. (2016). Perbedaan Hasil Belajar Siswa dalam Pembelajaran Kooperatif Tipe Jigsaw dengan Konvensional. In National Conference of Applied Engineering, Business and Information Technology (ASNI-Tech), 414-421.

Ismail, N. S., Harun, J., Aman, M., Megat, Z., \& Salleh, S. (2018). The Effect of Mobile Problem-Based Learning Application DicScience PBL on Students' Critical Thinking. Thinking Skills and Creativity, 28, 177-195. https://doi.org/10.1016/j.tsc.2018.04.002 
Jang, W.-D., \& Kim, C.-S. (2017). Online video object segmentation via convolutional trident network. Proceedings of the IEEE Conference on Computer Vision and Pattern Recognition, 5849-5858.

Jooste, J. L., Louw, L., von Leipzig, K., Conradie, P. D. F., Asekun, O. O., Lucke, D., \& Hagedorn-Hansen, D. (2020). Teaching maintenance plan development in a learning factory environment. Procedia Manufacturing, 45, 379-385. https://doi.org/10.1016 /j.promfg.2020.04.040

Kim, M. K., Wang, Y., \& Ketenci, T. (2019). Who Are Online Learning Leaders? Piloting a Leader Identification Method (LIM). Computers in Human Behavior, 105. https://doi.org/10.1016/j.chb.2019.106205

Kramer, C., König, J., Strauß, S., \& Kaspar, K. (2020). Classroom videos or transcripts? A quasi-experimental study to assess the effects of media-based learning on pre-service teachers' situation-specific skills of classroom management. International Journal of Educational Research, 103(June). https://doi.org/10.1016/j.ijer.2020101624

Kumari, T. A., Hemalatha, C. H., Ali, M. S., \& Naresh, R. (2020). ScienceDirect ScienceDirect Procedia ScienceDirect Survey on Impact and a Learning â€ $€^{\mathrm{TM}} \mathrm{s}$ of the. Procedia Computer Science, 172, 82-91. https://doi.org/10.1016/j.procs.2020.05.167

Laar, E. Van, Deursen, A. J. A. M. Van, Dijk, J. A. G. M. Van, \& Haan, J. De. (2020). Determinants of 21st-Century Skills and 21st-Century Digital Skills for Workers: A Systematic Literature Review, 10(1). https://doi.org/10.1177/2158244019900176

Lee, K. S., \& Chen, W. (2017). A long shadow: cultural capital, techno-capital and networking skills of college students. Computer Human Behavioral., 70, 67-73. https://doi.org/https://doi.org/ 10.1016/j.chb.2016.12.030

Luke, B., \& Hogarth, K. (2011). Developing and enhancing independent learning skills Using video tutorials as a means of helping. https://doi.org/10.1108/1030961111 187019

Maddison, T., Doi, C., Lucky, S., \& Kumaran, M. (2017). Literature Review of Online Learning in Academic Libraries. Distributed Learning, https://doi.org/10.1016/B978-008-100598-9.00002-7

Maryuningsih, Y., Hidayat, T., Riandi, R., \& Rustaman, N. Y. (2019). Critical thinking skills of prospective biology teacher on the chromosomal basic of inheritance learning through online discussion forums. Journal of Physics: Conference Series, 1157(2). https://doi.org/10.1088/1742-6596/1157/2/022090

Mengual-Andrés, S., Roig-Vila, R., \& Mira, J. B. (2016). Delphi study for the design and validation of a questionnaire about digital competences in higher education. International Journal of Educational Technology in Higher Education, 13(1). https://doi.org/10.1186/s41239-016-0009-y

Meyer, O., Omdahl, M., \& G, M. (2010). Investigating the effect of pre-training when learning through immersive virtual reality and video: A media and methods experiment. 
Computers \& Education, 140, 103.

Meyers, L. S., Gamst, G., \& Guarino, A. J. (2016). Applied multivariate research: Design and interpretation. Sage publications.

Mohamad, N., Osman, K., Mastura, T., \& Soh, T. (2011). Instrument development for 21st century skills in Biology. 15, 1470-1474. https://doi.org/10.1016/j.sbspro. 2011.03.312

Mohammed, A., Qadha, H., \& Alward, M. A. (2020). The e ff ect of using videos in teaching and learning English present progressive tense. 17(2), 159-170. https://doi.org/10.1108/ITSE-08-2019-0045

Musa, F., Mufti, N., Latiff, R. A., \& Amin, M. M. (2012). Project-based learning ( PjBL ): inculcating soft skills in 21 century workplace. 59(2006), 565-573. https://doi.org/10.1016/j.sbspro.2012.09.315

Nortvig, A., Petersen, A. K., \& Balle, S. H. (2018). A Literature Review of the Factors Influencing E-Learning and Blended Learning in Relation to Learning Outcome, Student Satisfaction and Engagement. 16(1), 46-55.

Nur, W., \& Wan, T. (2019). Journal of Technology and Science Education ONLINE INTERACTION IN SOCIAL LEARNING ENVIRONMENT. 9(1), 4-12.

Ongardwanich, N., Kanjanawasee, S., \& Tuipae, C. (2015). Development of 21 st Century Skill Scales as Perceived by Students. Procedia - Social and Behavioral Sciences, 191, 737-741. https://doi.org/10.1016/j.sbspro.2015.04.716

Pheeraphan, N. (2013). Enhancement of the 21 st Century Skills for Thai Higher Education by Integration of ICT in Classroom. Procedia - Social and Behavioral Sciences, 103, 365-373. https://doi.org/10.1016/j.sbspro.2013.10.346

Rusli, R., Rahman, A., \& Abdullah, H. (2020). Student perception data on online learning using heutagogy approach in the Faculty of Mathematics and Natural Sciences of Universitas Negeri Makassar , Indonesia. Data in Brief, 29. https://doi.org/10.1016/j.dib.2020.105152

Schulze, J., Schultze, M., West, S. G., \& Krumm, S. (2017). The Knowledge, Skills, Abilities, and Other Characteristics Required for Face-to-Face Versus ComputerMediated Communication: Similar or Distinct Constructs? Journal of Business and Psychology, 32(3), 283-300. https://doi.org/10.1007/s10869-016-9465-6

Scott, J. 2009. The Effect of Information Technology on Economic Education. Journal of Economic Education, 40(4), 337-353. http://dx.doi.org/10.1080/002204809 03237901 .

Selat, D. I. S. D. N., Lanang, I. G., Kartika, A., Tastra, I. D. K., \& Suwatra, I. G. N. I. W. (2014). Pengembangan media video pembelajaran dengan model addie pada pembelajaran bahasa inggris, e-Jurnal Edutech Universitas Pendidikan Ganesha. (5).

Siddiq, F., Scherer, R., \& Tondeur, J. (2016). Computers \& Education Teachers â $€^{\mathrm{TM}}$ 
emphasis on developing students â $€^{\mathrm{TM}}$ digital information and communication skills (TEDDICS): A new construct in 21st century education. Computers \& Education, 9293, e48-e50. https://doi.org/10.1016/j.compedu.2015.10.006

Singh, V., \& Thurman, A. (2019). How Many Ways Can We Define Online Learning? A Systematic Literature Review of Definitions of Online Learning ( 1988-2018) How Many Ways Can We De fi ne Online Learning? A Systematic. American Journal of Distance Education, 33(4), 289-306. https://doi.org/10.1080/08923647.2019.1663082

Slota, M., Mclaughlin, M., Bradford, L., Julia, F., \& Vittone, S. (2017). Visual intelligence education as an innovative interdisciplinary approach for advancing communication and collaboration skills in nursing practice. Journal of Professional Nursing, 34(5), 357-363. https://doi.org/10.1016/j.profnurs.2017.12.007

Smith, T. E. (2018). Teaching critical thinking in a GE class: A flipped model. Thinking Skills and Creativity, 28, 73-83. https://doi.org/10.1016/j.tsc.2018.02.010

Sulisworo, D., Ummah, R., Nursolikh, M., \& Rahardjo, W. (2020). The analysis of the critical thinking skills between blended learning implementation : google classroom and schoology. Universal Journal of Educational Research, 8, 33-40. https://doi.org /10.13189/ujer.2020.081504

Thomas, S. (2019). Flipped classroom pedagogy: Using pre-class videos in an undergraduate business information systems management course. Education + Training, 61(6), 756-774. https://doi.org/10.1108/ET-06-2018-0133

Tsai, D., Flagg, M., Nakazawa, A., \& Rehg, J. M. (2012). Motion coherent tracking using multi-label mrf optimization. International Journal Computer Vision, 100(2), 190-202.

van Laar, E., van Deursen, A. J. A. M., van Dijk, J. A. G. M., \& de Haan, J. (2017). The relation between 21 st-century skills and digital skills: A systematic literature review. Computers in Human Behavior, 72, 577-588. https://doi.org/10.1016/j.chb.2017.03.010

van Laar, E., van Deursen, A. J. A. M., van Dijk, J. A. G. M., \& de Haan, J. (2018). 21st-century digital skills instrument aimed at working professionals: Conceptual development and empirical validation. Telematics and Informatics, 35(8), 2184-2200. https://doi.org/10.1016/j.tele.2018.08.006

Laar, E. Van, Deursen, A. J. A. M. Van, Dijk, J. A. G. M. Van, \& Haan, J. De. (2020). Determinants of 21st-Century Skills and 21st-Century Digital Skills for Workers : A Systematic Literature Review. https://doi.org/10.1177/2158244019900176

Varga, V. (2020). Neurocomputing Reducing human efforts in video segmentation annotation with reinforcement learning. 405, 247-258. https://doi.org/10.1016/ j.neucom.2020.02.127

Villalba, E., \& Cedefop, T. (2017). Critical thinking in relation to creativity. Reference Module in Neuroscience and Biobehavioral Psychology. https://doi.org/10.1016/B9780-12-809324-5.06160-5 
Voogt, J., \& Roblin, N. P. (2012). A comparative analysis of international frameworks for 21 st century competences: Implications for national curriculum policies. Journal of Curriculum Studies, 44(3), 299-321. https://doi.org/10.1080/00220272.2012.668938

Wahyu, A., Wirawan, Dyah, C., Indrawati, S., \& Rahmanto, A. N. (2017). Pengembangan Media Pembelajaran Kearsipan Digital Untuk Meningkatkan Hasil Belajar Siswa Smk Negeri 3 Surakarta the Development of Learning Media Archives To Improve Student Learning Outcomes Smk Negeri 3 Surakarta. Jurnal Pendidikan Vokasi Februari, 7(2017), 78-86. Retrieved from http://journal.uny.ac.id/index.php/jpv

Wang, J., Antonenko, P., \& Dawson, K. (2020). Does visual attention to the instructor in online video affect learning and learner perceptions? An eye-tracking analysis. Computers \& Education, 146. https://doi.org/10.1016/j.compedu.2019.103779

Wechsler, S. M., Saiz, C., Rivas, S. F., Maria, C., Vendramini, M., Almeida, L. S., Franco, A. (2017). Creative and critical thinking: Independent or overlapping components?. Thinking Skills and Creativity, 27, 114-122. https://doi.org/10.1016 j.tsc.2017.12.003

Wilson, J. L., Whyte, R. I., Gangadharan, S. P., \& Kent, M. S. (2017). Teamwork and Communication Skills in Cardiothoracic Surgery. The Annals of Thoracic Surgery, 103(4), 1049-1054. https://doi.org/10.1016/j.athoracsur.2017.01.067

Yang, L., Han, J., Zhang, D., Liu, N., \& Zhang, D. (2018). Segmentation in weakly labeled videos via a semantic ranking and optical warping network. IEEE Trans. Image Process, 27(8), 4025-4037.

Ye, Y., Zhang, S., Li, Y., Qian, X., Tang, S., \& Pu, S. (2020). Video question answering via grounded cross-attention network learning. Information Processing and Management, 57(4). https://doi.org/10.1016/j.ipm.2020.102265

Yun, S., Choi, J., Yoo, Y., Yun, K., \& Choi, J. Y. (2017). Action-decision networks for visual tracking with deep reinforcement learning. Proceedings of the IEEE Conference on Computer Vision and Pattern Recognition, 2711-2720.

Zhang, D., Han, J., Yang, L., \& Xu, D. (n.d.). Spftn: a joint learning framework for localizing and segmenting objects in weakly labeled videos. IEEE Trans. Pattern Anal. Mach. Intelligence.

Zhang, D., Zhou, L., Briggs, R. O., \& Nunamaker, J. F. (2006). Instructional video in elearning: Assessing the impact of interactive video on learning effectiveness. 43, 1527. https://doi.org/10.1016/j.im.2005.01.004 


\section{APPENDIX A. QUESTIONARY STATEMENT ITEMS}

\section{Students' learning and innovation skills}

Communication skills

1. I like to share ideas with friends

2. I like listening to friends' ideas

3. I often deliver my answers and ideas to others

4. I like to be actively involved in the archiving class

Creativity skills

1. I often come up with new ideas in the archiving class

2. I use a different strategy from my friends in doing my assignment of the archiving subject

3. I like activities that produce creative products

4. I like brainstorming activities (gathering in groups, then expressing new ideas spontaneously)

Collaboration skills

1. I like to complete assignments in groups

2. I like to help my friends understand archiving material

3. I like to tolerate friends

4. I like the product produced in group work

Critical thinking skills

1. I like solving problems in archiving subject

2. I like to search for information from various sources

3. I can explain my reasons when delivering my chosen answer

4. I like problems or assignments related to reasoning, such as comparing, differentiating, and classifying

\section{Online learning}

1. I can operate applications for online learning (Google Classroom, Zoom Meeting, and other online learning applications)

2. I can understand the lessons explained by the teacher through the online application very well

3. I can understand the assignment given by the teacher through the online learning application

4. I always search for certain information via the internet

5. I learn on the internet every day

6. I search for learning materials via the internet every day

7. Learning through online applications is easier to understand than learning in school

8. Online learning makes it easier for me to understand a material

9. I prefer online learning rather than learning in person at school

Utilization of archival learning videos

1. I can open archiving learning videos easily

2. I can operate archiving learning videos easily

3. I can understand archiving material easily through archiving learning videos

4. The material presented in the video is in accordance with the material taught by 
the teacher

5. Archiving learning videos can help me understand the material

6. The archiving practice presented in the video is easy to understand and practice 